\title{
Characteristic Morpho-Phisiological Aspects of Fat Spherules and Cellular Conglomerates of Goat and Sheep Milk
}

\author{
Alina NASALEAN ${ }^{1}$, Laurenț OGNEAN ${ }^{1 *}$, Cristina ȘTEFANUȚ ${ }^{1}$, Sanda ANDREI ${ }^{2}$, Rodica SOMEȘAN ${ }^{1}$ \\ ${ }^{1}$ University of Agricultural Science and Veterinary Medicine, Department of Physiology, Calea \\ Mănăștur no. 3-5, 400037, Cluj-Napoca, Romania, \\ ${ }^{2}$ University of Agricultural Science and Veterinary Medicine, Department of Biochemistry, Calea \\ Mănăştur no. 3-5, 400037, Cluj-Napoca, Romania. \\ Corresponding author: lognean@yahoo.com
}

Bulletin UASVM Veterinary Medicine 72(1) / 2015,

Print ISSN 1843-5270; Electronic ISSN 1843-5378

DOI:10.15835/buasvmcn-vm: 10497

\begin{abstract}
The small size of fat spherules, the abundance of atypical cells, cellular debris and anuclear formations are the fundamental morphologic characteristics of goat milk that can differentiate it from sheep milk. The aim of the study is the characterisation of morphology, activity of spherules and their conglomerates, as well as cellular structures and acellular formations in goat and sheep milk. Thus, there have been morphophysiological characterisations of colostrums and fresh goat $(\mathrm{n}=26)$ and sheep $(\mathrm{n}=54)$ milk, obtained from clinically healthy animals from native breeds, using the Squash technique and panoptic (Dia-Quik-Panoptic) and Gram staining. The microscopic exams revealed the abundance of small fat spherules in goat milk compared with sheep milk. This property was considered the main morphologic element that can be used to microscopically differentiate milk from the two species, being correlated as well with the high digestibility degree of goat milk. In the cytomorphologic configuration we also found atypical formations, isolated or in conglomerates with fat spherules, whole cells or cellular debris. They were characterised by polymorphism and variable frequency, being very abundant in goat colostrums (++++) and extremely rare in sheep colostrums (+). In goat milk in full lactation we also found oval or polygonal epieliocytes with porous nucleus that may be derived from epithelium of the milk cistern or the great galactophorus ducts. In conclusion, the obtained results highlight the necessity of quantitative and qualitative cytomorphologic tests as well as their correlation for the health and safety evaluation of milk used for consumption as food.
\end{abstract}

Keywords: activity state, colostums, goat, milk, morphology, sheep.

\section{INTRODUCTION}

Milk is a secretion of the mammary gland (Mahe, 1997), being a heterogeneous dispersed system, in which lactose and mineral salts form real solutions, the protein substances are found in colloidal form and fat is presented as an emulsion. Fat represents the most variable component of milk (German and Dillard, 2006), being influenced by genetic factors, breed, lactation period, mammary gland health, feeding, climatic factors, as well as the state in which milk is found. Studies regarding the cytology of goat and sheep milk take importance only after the year 1990 (Jandal, 1996). Thus, there is not that much available data regarding the surveillance of mammary gland health based on lacto-cytological tests in these species. The data regarding goat milk arises many controversies as to the configuration and number of contained cells (David et al., 1995). Even so, in goat milk we may consider characteristic the high frequency of atypical cells, cellular debris and anuclear formations (Ognean, 2002). The cytological investigations on sheep milk are still sporadic and the data is usually only in comparison with dairy milk and, more often, with goat milk.

\section{AIMS AND OBJECTIVES}

The aim of this research is the cytomorphological characterisation of fat spherules, 
their conglomerations and the cellular and acellular formations of goat and sheep milk of healthy animals.

\section{MATERIALS AND METHODS}

In this study there we have performed microscopic examinations of cytological preparations obtained mixed samples of milk and freshly collected samples of colostrums from clinically healthy 26 goats and 54 sheep of indigenous breeds. Thus there we have used Squash staining technique (Dia-Quik-Panoptic) and Gram staining technique (Sabău and Rotaru, 2006). The evaluation of the microscopic preparations was concentrated on qualitative criteria that consisted in the characterisation of cyto-morphologic aspects and cellular activity, as well as quantitative criteria, using the lactogram method.

\section{RESULTS AND DISCUSSION}

The morpho-functional characteristics revealed through the qualitative and quantitative examinations show a significant heterogeneity of the macrophage population within which there is a predominance of active cells $32-38 \%$ and hyperactive cells in coslostrum between $17-27 \%$. These results indicate an increased level of the self-defence capacity of the mammary gland.

The examination of the vital preparations highlighted the small dimensions of goat milk fat spherules compared with sheep milk ones, characteristic that increases the digestibility of goat milk compared to sheep milk.

Themicroscopicexamsrevealed theabundance of small fat spherules of goat milk compared with the ones found in sheep milk. This property was considered the main morphologic element that permits the microscopic differentiation of milk from the two species, being correlated as well with the high digestibility of goat milk. In the cytomorphological configuration we also reported atypical formations, isolated or in conglomerates with fat spherules, whole cells or cellular debris. They were characterised by polymorphism and variable frequency, being very abundant in goat colostrums (++++) and extremely rare in sheep milk (+). In goat milk samples collected in full lactation there were reported oval or polygonal form epitheliocytes with porous nucleus that may derive from the epithelium of the milk cistern of the great galactophorous ducts.

\section{CONCLUSION}

The obtained results support the necessity of quantitative and qualitative cyto-morphological tests and their correlation in order to evaluate the health and safety of goat and sheep milk used for consumption as food.

\section{REFERENCES}

1. German JB, Dillard CJ (2006). Composition, structure and absorption of milk lipids: a source of energy, fat-soluble nutrients and bioactive molecules. Critical Reviews in Food Science of Nutrition 46:57-92.

2. Jandal IM (1996). Comparative aspects of goats and sheep milk. Small Ruminant Research 22:177-185.

3. Mahe' S (1997).Valeur nutritionnelle du lait en alimentation humaine.Interets nutritiounel et dietetique du lait chevre. Les Colloques. INRA 81:9-24.

4. Ognean L (2002). Aspecte morfofiziologice caracteristice populațiilor celulare din lapte şi particularitățile lactocitogramei. Revista Română de Medicină Veterinară 12(1-2):27-38.

5. Sab?u Diana, Rotaru O (2006). Celule somatice şi s?n?tatea laptelui . AcademicPres, Cluj-Napoca.

6. Wilson DJ, Stewart KN, Sears PM (1995). Effects of stage of lactation, party production, party and season on somatic cell counts in infected and undinfected dairy goats. Small Ruminant Research 16:165-169. 